\title{
Regulating surplus: charity and the legal geographies of food waste enclosure
}

\author{
Joshua D. Lohnes ${ }^{1}$ iD \\ Accepted: 8 September 2020 / Published online: 12 September 2020 \\ (c) Springer Nature B.V. 2020
}

\begin{abstract}
Food charity in the United States has grown into a critical appendage of agro-food supply chains. In 2016, 4.5 billion pounds of food waste was diverted through a network of 200 regional food banks, a fivefold increase in just 20 years. Recent global trade disruptions and the COVID-19 pandemic have further reinforced this trend. Economic geographers studying charitable food networks argue that its infrastructure and moral substructure serve to revalue food waste and surplus labor in the capitalist food system. The political-legal framework undergirding this revaluation process however is still poorly understood. Drawing on a 6-year institutional ethnography of the food banking economy in West Virginia, this paper takes a supply-side approach to examine the material and moral values driving the expansion of food waste recovery as hunger relief. Empirically, it focuses on the laws, contracts and fiscal incentives regulating charitable food procurement at the U.S. Department of Agriculture and Feeding America. The assemblage of government agencies, private businesses and non-profit organizations enrolled into this gift economy at different scales I argue, serves to enclose food waste into a public-private governance structure that regulates food surpluses and ensures these will not disrupt the scarcity logics driving profitability along primary food circuits.
\end{abstract}

Keywords Hunger $\cdot$ Food charity $\cdot$ Food waste $\cdot$ Food policy $\cdot$ Supply chains $\cdot$ Value $\cdot$ Food regime

$\begin{array}{ll}\text { Abbreviations } \\ \text { AMS } & \text { Agricultural Marketing Service } \\ \text { ARRA } & \text { American Recovery and Reinvestment Act } \\ \text { CCC } & \text { Commodity Credit Corporation } \\ \text { CFAP } & \text { Coronavirus Food Assistance Program } \\ \text { IRS } & \text { Internal Revenue Service } \\ \text { FA } & \text { Feeding America } \\ \text { FMV } & \text { Fair Market Valuation } \\ \text { FNS } & \text { Food and Nutrition Service } \\ \text { LFC } & \text { Local Food Charity } \\ \text { PATH Act } & \text { Protecting Americans from Tax Hikes Act } \\ \text { PROWA } & \begin{array}{l}\text { Personal Responsibility and Work Opportu- } \\ \text { nity Reconciliation Act }\end{array} \\ \text { SNAP } & \text { Supplemental Nutrition Assistance Program } \\ \text { TEFAP } & \text { The Emergency Food Assistance Program } \\ \text { USDA } & \text { United States Department of Agriculture }\end{array}$

Joshua D. Lohnes

jlohnes@mail.wvu.edu

1 Department of Geology and Geography, West Virginia University, 98 Beechurst Ave, Morgantown, WV 26506, USA

\section{Introduction}

The COVID-19 pandemic has re-exposed the long-standing paradox between waste and want in our food system. As farmers dump milk, euthanize animals and plow under crops due to supply chain bottlenecks and plummeting market demand for their products, millions of people left without a reliable source of income are lining up to receive free boxes of food from local charities overwhelmed with the sudden need. In the United States, moral outrage over the visible production of food scarcity in the context of long feeding lines has unlocked large amounts of public and private funding to divert food excess toward charities serving people facing economic precarity. As the fallout from the novel coronavirus continues to affect the institutions that shape and govern food assistance programs, it is critical to reflect on the antecedents that led to the present charitable food response and their implications for policy advocates and activists building a more resilient food future.

Food waste generated across agro-food supply chains is not a new phenomenon. Indeed, prior to the latest supply chain disruptions 62 million tons of food were discarded from field to plate each year in the United States, $40 \%$ of 
overall food production (Broad Leib et al. 2017; ReFED 2019). Globally, roughly a third of all edible food is not consumed by humans, a fact that is increasingly generating a sense of moralized panic in the context of food system inefficiencies, household food insecurity and anxiety over greenhouse gas emissions (Spring et al. 2020). Rising social awareness over the dire environmental and economic costs of this problem has led to a flurry of food waste reduction schemes, the most prominent of which centers on regional food banks and their network of local food charity (LFC) affiliates.

The food banking model that first emerged in the United States over 40 years ago, has progressively spread across the industrialized world (Riches and Silvasti 2014) and now plays a critical role in both the roll back and roll-out of neoliberal welfare policy (Peck and Tickell 2002; Warshawsky 2010; Dickenson 2020). The political and economic dynamics driving the growth of food charity is a growing field of inquiry for social scientists concerned with the erosion of public entitlement programs and the rise of a secondary welfare system that devolves the state from its responsibility to guarantee the right to food. Because food is essential to life, wasted food is also increasingly embedded with moral values when placed in the context of hunger (Lorenz 2012; Salonen 2018). The laws written to contain or overcome the food waste-hunger paradox tend to achieve temporary "consensus frames" (Arcuri 2019) whose ambiguity fails to address the underlying root causes driving the over-production of food in the midst of household food insecurity (Lambie-Mumford 2019). Riches (2018) coalesces the discomfort many charitable food scholars feel with the corporate capture of food assistance programming and the uncritical solidarity that justifies feeding "wasted food, surplus to the requirements of a dysfunctional food system, to millions of hungry citizens who are surplus to the requirements of the labor market" (p. 1). Yet, as the COVID-19 crisis has clearly revealed, charity continues to act as a powerful social imaginary for policy makers and large food conglomerates eager to resolve food system inefficiencies.

In this paper, I review the legal framework regulating the charitable food industry in the United States through a supply-side approach. I build on the work of economic geographers who argue that charitable food networks function as secondary circuits of accumulation for the capitalist food economy, revaluing industrial food waste that could not be sold through primary channels, by redistributing excess to the poor (Henderson 2004; Lindenbaum 2016; Lohnes and Wilson 2018). Rather than focusing on the demand for emergency food or the conditions leading to household level food insecurity, my analysis highlights the function that charitable food infrastructure, and its attendant moral substructure, play in regulating food abundance in society (Salonen 2018; Gille 2012).
After a review of the literature exploring the material and moral values embedded in food waste recovery as hunger relief, I trace the evolution of the political, legal and institutional framework within which public-private charitable food procurement has come to exist in the United States. I highlight some of the ways that food charity encloses food waste into non-profit distribution channels that ensure donations do not disrupt the profit motives driving dominant agro-industrial supply chains. I also reflect on the charitable food policies most recently enacted as a response to the COVID-19 crisis, and the opportunity that "the pandemic as a portal" (Roy 2020) presents food scholars and activists to engage with rapidly changing policy dynamics in the food system in general, an food charity in particular. The explosion of humanitarian food initiatives responding to this crisis across the world should open new lines of inquiry and activism with a view toward strengthening the networks of resistance to dominant power relationships currently structuring our foodways along lines of disposable income. ${ }^{1}$ Understanding the multi-scalar constraints and opportunities available to enact change across the networks of care serving people most vulnerable to hunger must however remain of key concern in these efforts.

\section{Methods}

I excavate the legal geography shaping the organization of food charities across space and scale in the United States by drawing on a 6-year institutional ethnography (Billo and Mountz 2016) of charitable food networks in West Virginia. This research unfolded in conjunction with the development of WV FOODLINK, a public geography project that maps access to food entitlements in the state and serves as a resource for various social service organizations and anti-hunger policy advocates. Data collection for this project involved working closely with the state's two regional food banks, both Feeding America (FA) members. It also involved mapping the variable capacity of their 550 local food charity (LFC) affiliates to access and distribute food. Participant observation provided insights and documentation into the governance mechanisms structuring food charity in West Virginia, and the United States more broadly.

Because access to food banking resources extend far beyond state borders, I also conducted interviews with FA employees, bureaucrats administering The Emergency Food

\footnotetext{
${ }^{1}$ Food banks and their LFCs distribute food to people who do not have sufficient incomes to pay for it. Although they provide access to food, they do not address one of the key drivers of household food insecurity namely insufficient income (acquired through wages or cash-equivalent entitlement) to access adequate food in the marketplace.
} 
Assistance Program (TEFAP) at the U.S Department of Agriculture (USDA) and private contractors selling food to the federal government. I attended three national conferences that drew charitable food actors from across the country together to discuss issues facing anti-hunger organizations and exchange ideas on national, regional, and local food distribution strategies. These event ethnographies (Duffy 2014) served to identify organizational patterns across charitable food networks, key actors and power differentials among them, and the way that these fit within the wider agri-environmental governance assemblage (Forney et al. 2018).

Food charity, as governance assemblage, is enacted through the coming together of multiple actors in the private, public and non-profit sectors, each with diverse goals and power positions to influence the laws that shape access to food surplus (or waste) and the resources needed to recover and re-distribute it (Galli et al. 2019). It is to these rules of this public-private assemblage that the findings in this paper attend to, relying primarily on legal archives, clarifying memos and contracts signed between parties involved in charitable food sourcing and distribution transactions. Therefore, while data from over 65 semi-structured interviews and dozens of webinars, conference calls and other advocacy work are not prominently featured in the paper, these do serve to interpret how these rules transcend organizational boundaries to shape charitable food institutions and the practice of recovering food waste as hunger relief.

\section{Material and moral values of food waste as hunger relief}

As both a social hazard and a potential actant in addressing food access failure, food waste disturbs and disrupts sociospatial norms (Moore 2012) and the rules that emerge to govern its function in society are thus an ongoing political contest over economic and social values (Midgley 2014; Mourad 2016; Lambie-Mumford 2019; Spring et al. 2020). As food commodities move out of commercial supply chains into the sphere of charitable giving, laws and contracts reinscribe food waste with different meanings contingent on its perceived value by different actors taking part in the gift transaction (Blake 2019).

Food waste is tied to the organization of production and consumption across agro-industrial supply chains particularly the avoidance of risk by states, speculators, farmers, food processors, retailers, and consumers (Stuart 2009; Bloom 2010). Food waste regimes emerge among these different actors to regulate the distribution of food surpluses to protect and maintain existing value chains in the global food economy (Gille 2012). Repurposing food waste as hunger relief is thus embedded within the political ecology of contemporary agri-food systems (Galt 2013) and the state's evolving yet critical function in maintaining profit imperatives therein (Friedmann 2005; McMichael 2009).

In the United States, the relationship between food waste and hunger is a century-old dilemma, one that has a long legal history of mitigating social discontent associated with the contradictions of "breadlines knee deep in wheat" (Poppendieck 2014). New Deal food policies first reconciled the moral outrage of massive food surpluses amidst household food insecurity brought on by the Great Depression. Specifically, the 1933 Agricultural Adjustment Act empowered the USDA to purchase surplus commodities from farmers facing production gluts and redistribute the excess as hunger relief through county governments, morphing into initial food stamp program in 1939 (Landers 2007).

The Commodity Credit Corporation (CCC), created to finance these government food purchases, continues to be used as a central mechanism to stabilize a U.S. farm sector facing endemic downward price pressures due to overproduction. Borne out of a crisis of surplus and scarcity, the Agricultural Adjustment Act remains the basis for the quadrennial farm bill that continues to structure food and nutrition policy in the United States. This tension between food waste and hunger is thus literally coded into federal food policy. The legislation's near century evolution has not resolved the underlying crisis of overproduction and household food insecurity endemic to contemporary agri-food systems, rather the farm bill continues to set into motion a series of fixes through which food production and nutrition entitlement have developed into the twenty-first century (Graddy-Lovelace and Diamond 2017).

The USDA is the largest food aid organization in the world. ${ }^{2}$ In 2017, the federal government spent $\$ 112$ billion on domestic food entitlement programs to ensure that people with limited purchasing power in the marketplace could access food. The Supplemental Nutrition Assistance Program (SNAP) accounts for the largest proportion of this funding ${ }^{3}$ ( $\$ 79$ billion), followed by school nutrition programs ( $\$ 22$ billion) and the Special Supplemental Nutrition Program for Women Infants and Children (WIC) (\$6 billion). The charitable food economy is undergirded by two of the dozen other federal nutrition assistance programs namely TEFAP (\$374 million) and the Commodity Supplemental Food Program (CSFP) (\$205 million). ${ }^{4}$ As of April 2020,

\footnotetext{
${ }^{2}$ Though the United Nations World Food Program serves an average of 90 million people each year through humanitarian food aid, its budget stands at a mere $\$ 1$ billion dollars, one hundred times smaller than U.S. domestic food assistance programs.

${ }^{3}$ SNAP grew out of the food stamp program and efforts to distribute excess farm commodities during the Great Depression.

${ }^{4}$ For a full review of federal nutrition assistance programs and their relationship to household food insecurity in the United States see Coleman-Jensen et al. (2016).
} 
the newly formed Coronavirus Food Assistance Program (CFAP), allocated $\$ 16$ billion as direct relief to producers, and $\$ 3$ billion of food purchases to be distributed to charities through the Farmers to Families Food Box Program. This model will likely crystallize into yet another food waste stream for non-profit feeding networks. Congress also significantly increased allocations to TEFAP appropriating \$2.5 billion for the program in response to the COVID-19 crisis (USDA 2020).

Charity as nutrition entitlement first made its appearance in federal law in the early 1980s and has steadily captured the policy imagination of legislators eager to demonstrate that they are working to resolve food insecurity concerns in their districts. Food charity is perceived as a caring, nimble, bottom-up response to hunger, one driven by sentiments of mutual aid and solidarity at the neighborhood level. While this is one of the key factors maintaining LFCs in place and linked across space, such perspectives obscure the essential role played by top-down legislative fixes to the dyad of agricultural overproduction and food access failure endemic to profit-driven food systems (De Castro 1977; Vernon 2007; Chappell 2018). The poor have very little influence in shaping the laws that provide them with access to food entitlements. Though anti-hunger coalitions form at different scales to speak on their behalf, corporate lobbying power has an outsized influence on food and nutrition policy and has captured anti-hunger advocacy efforts through policies that favor entrenched interests in the farm, food processing and retail sectors (Fisher 2017).

Food waste does not move from places of excess to places of dearth on its own, doing so requires significant amounts of capital inputs into distribution infrastructure (labor, warehouses, vehicles, software systems etc.). It also requires the ability to access the narrative surrounding the (re)production of empathy for hunger related causes. As Henderson (2004) aptly noted after spending extensive time volunteering at a regional food bank, the food flowing through charitable networks does not neatly map onto normal circulations of value but rather operates as "a separate circuit for the realization of use value and for the suspension of exchange value" (p. 490) where food commodities gain a new life through the production of specific "socially necessary representations"(p. 505 ) of both food banking work and food aid recipients. The networks of power that leverage the state to address the paradox of surplus and scarcity in the U.S food system have progressively institutionalized charity as the response to the material and moral dilemmas faced by a corporate environmental food regime that is "deepening inequalities between rich and poor eaters" (Friedmann 2005, p. 228).

On the material side, a financialized food system overproduces food to generate shareholder profit (Burch and Lawrence 2009) even as low wages and inadequate public investments in social safety net programs leave millions of people without access to a nutritious diet (Araghi 2003; Dickenson 2020). Sen's (1981) seminal entitlement theory ${ }^{5}$ reminds us that food access failure must be understood in relationship to food distribution mechanisms in place in any given society and that vulnerability to hunger evolves alongside wider socio-political and economic changes. Securing the right to food in a given time and place must therefore be understood in relationship to the ability, or lack thereof, that people, particularly the most vulnerable, have to shape the broad societal forces informing food distribution, and their level of enfranchisement within those structures (Watts and Bohle 1993). In the United States, food entitlement, and indeed household food security, is tightly linked to income and the capacity to secure money in exchange for food in the marketplace.

On the moral side, household level food scarcity mobilizes compassion to recover and redistribute foods that could not be sold through traditional market channels as an unquestionable social imperative. The institutionalization and entrenchment of food charity over the past 4 decades continues to provide what Poppendieck (1998) aptly identified as a "moral safety valve" for a society coming to grips with deepening levels of income inequality. Since her critique was leveled over 20 years ago, charity continues to evolve as a social strategy that deals with the moral dilemmas associated with distributing abundance (McIntyre et al. 2016). The vast majority of workers engaging in food charity are not paid to distribute food waste, they do so freely, out of goodwill and compassion toward others. Yet the principal actors donating food do receive material benefits through tax incentives, government payments, marketing and promotion opportunities. Rather than wrestling with the paradox of a food system that simultaneously produces worrisome levels of food surplus and hunger, charity decriminalizes excess by turning our moral gaze toward food poverty rather than on the political process involved in determining whom should have the right to control abundance in society (Salonen 2018).

The laws regulating charitable food in the United States must thus be understood at the intersection of this tension between the material and moral values that shape access to food excess. Material value as expressed in the money form, intersects with moral value as expressed in the charitable will to act on the imperative to redistribute food excess to the poor. This tension is present at each node of the charitable

\footnotetext{
${ }^{5}$ Food access must be understood within the "set of commodity bundles that a person can command in a society using the totality of rights and opportunities he or she faces" (Sen 1981, p. 497). Sen identified four entitlements related to securing food: 1 . Production based entitlements (e.g. producing food). 2. Trade based entitlements (e.g. buying food). 3. Own-labor entitlements (e.g. working for food) and 4. Transfer entitlements (e.g. being given food by others).
} 
food network but finds its tenuous social consensus in the laws that regulate access to food waste as charitable gifts. The analysis I now turn to strongly points toward a social consensus currently structured around a politics of enclosure (Heynen and Robbins 2005; Vasudevan et al. 2008), one that ensures donated food waste does not disrupt the profit imperatives of the corporate food sector.

\section{Food charity: a public-private legal assemblage}

In 2016, 4.5 billion pounds of food was diverted from commercial supply chains through a network of 200 regional food banks, a fivefold increase in just 20 years (Feeding America 2017). The 60,000 local food charities (LFCs) integrated into this network raise money and mobilize volunteers to receive, process and serve industrial food waste to the 46 million people lining up each month to receive their portion of the excess (Winefield et al. 2014). While data is not yet available, all indicators point to COVID-19 deeply reinforcing these trends. Two institutions provide access to most of the food circulating through this network. First, the USDA purchases surplus agricultural commodities and allocates a portion to each state based on a statutory formula based on their unemployment and poverty rates. Second, FA encourages food corporations to donate their food waste to charity by coordinating charitable food supply chains and centralizing accounting procedures across the network. FA is the third largest charity in the country processing nearly $\$ 2$ billion dollars of tax-deductible receipts each year.

There are major differences between these two institutions. The first is a public program dually administered by the Agricultural Marketing Services (AMS) (via public food procurement contracts) and the Food and Nutrition Service (FNS) (via commodity distribution as nutritional entitlement). The second is a private philanthropic program, a highly professionalized element of the shadow state (Wolch 1990; Milligan 2007). Despite these vast organizational differences, there are important commonalities between the two. Each mandate that the food waste they govern be distributed exclusively through non-profit organizations that can prove and maintain updated records of their $501 \mathrm{c} 3$ status with the Internal Revenue Service. ${ }^{6}$ Each also interdicts the

\footnotetext{
${ }^{6}$ Under section 501(c) 3 of Title 26 of the United States Code, certain corporations may register as exempt from federal income tax if they can demonstrate that they do not operate for profit. Donors making cash or in-kind contributions to these non-profit organizations may also seek deductions to their federal income tax. Churches and other faith based organizations are automatically considered tax exempt and not required to apply for 501(c)3 status. However food banks must still maintain records of this special exemption on file for each of their members. In West Virginia, 80\% of food bank affiliates are faithbased organizations.
}

resale of donated food items. This secondary charitable food circuit thus provides an unconventional, yet increasingly essential, appendage of agro-food supply chains by enclosing the rising amounts of food waste into "re-gifting depots" that pass on the original gift of agricultural subsidies, taxbreaks, favorable trade policies, and reduced disposal costs first gifted to large food concerns (Lindenbaum 2016).

This public-private food waste revaluation assemblage is fractured across a diversity of regional and local charities where variable donor and volunteer capacity shapes access to food and monetary resources across geographies (Lohnes and Wilson 2018). Despite this seemingly uncoordinated response to hunger relief at the local scale, federal laws and the contracts that enforce them across space lubricate the gears of the charitable food economy in very specific ways. They expand the capacity and charitable food infrastructure in place to absorb and revalue food waste as hunger relief and ensure that the risks of overproduction and liberal procurement practices are mitigated for large food sector firms.

Since the early 1980s, the U.S. government has invested over $\$ 1.7$ billion into the infrastructure and administrative capacity of the charitable food economy and at least $\$ 13$ billion worth of food commodities through the TEFAP program alone. Recently agricultural trade mitigation programs and the new CFAP program have doubled down on these investments with another $\$ 6$ billion outlay, further spurring private philanthropic capital to invest in warehouses, refrigeration, trucks, office spaces and a labor force to keep charitable food supply chains open for food waste revaluation. The agglomeration of large food donors under the FA umbrella similarly paralleled the construction of a legal framework that incentivized food businesses to donate their obsolete inventories to charity and take advantage of the fair market valuation ${ }^{7}$ (FMV) deductions permissible under the federal tax code (Van Zuiden 2012).

The balance between public and private involvement in the network is constantly shifting. In 1984 for example, the federal government provided five times more food to the charitable food economy than private firms. That ratio flipped as corporate donations organized through FA have overtook TEFAP in volume. Most recently, the Trump administration released $\$ 1.2$ billion worth of federal commodities to mitigate the fall-out from agricultural surpluses resulting from its trade war with China (Paleta and Dewey 2018), flooding the network with public food once again. CFAP, launched in April 2020, will bring additional public funds into the network. In sum, the public and private

\footnotetext{
${ }^{7}$ FMV is the selling price of the donated product minus the costs of acquiring the product (Cost of Goods Sold) divided by 2. In other words, donors can write off half the unrealized profits from not having sold the item. Charitable contributions from a $\mathrm{C}$ corporation for a given year may not exceed $10 \%$ of their taxable net income.
} 
institutional responses to food waste recovery as hunger relief have co-evolved over the past 40 years. Rather than approaching the legal analysis chronologically however, I do so by institutional modality, focusing first on the laws and contracts regulating public charitable food procurement through TEFAP and most recently CFAP, prior to turning to the laws and contracts shaping the private (e.g. corporate) procurement through FA.

\section{Public procurement}

In the late 1970s and early 1980s, the federal government purchased and stockpiled over 500 million pounds of cheese and butter in state food warehouses across the country to stabilize milk markets and protect dairy farmers from bankruptcy. The state's capacity to intervene in this way was enabled by the institutional scaffold built under New Deal era food policy, namely the Commodity Credit Corporation (CCC). Created in 1933, CCC is a state enterprise under the general supervision of the Secretary of Agriculture "for the purpose of stabilizing, supporting, and protecting farm income and prices" (Commodity Credit Corporation Charter Act 1949). Public procurement for charitable food finds its origins in this massive liquid milk and cheese glut.

The paradox of mountains of cheese rotting in government storehouses in a context of rising homelessness and food insecurity rates spurred by harsh neoliberal austerity measures became a rallying cry for anti-hunger groups exposing contradiction in federal food and economic policy. Political pressure on the Reagan administration to act led to the creation of the Special Dairy Distribution Program (SDDP) by executive order. In 1983, Congress formalized the program under the name Temporary Emergency Food Assistance Program and authorized an appropriation of $\$ 50$ million per year for its administration (Lipsky and Thibodeau 1988). Designed as a temporary fix to an immediate political problem, the sudden availability of free surplus available at participating charities led to the depletion of federal commodity inventories in $<5$ years.

Rather than reverse the adverse effects of welfare reform to address the problem of hunger, The Hunger Prevention Act of 1988 directed \$120 million toward the annual purchase of farm goods in addition to existing CCC contracted excesses and the $\$ 50$ million earmarked to manage distribution logistics. By 1990, TEFAP's name was officially changed to The Emergency Food Assistance Program reflecting the permanent place it had come to secure in the USDA's nutrition assistance programming. Food banking and by extension the local charitable networks formed out of those aggregation and distribution centers were thus formerly fixed in place as an appendage of federal food policy.
By 1996 the Personal Responsibility and Work Opportunity Reconciliation Act (Clinton's Welfare Reform Law) further rolled back public entitlement programs all but decimating the Temporary Assistance for Needy Families (TANF) program. PROWA led to a further roll out of and structuring of TEFAP. The law defined the formula used to allocate food and funding to each state ${ }^{8}$ and codified the role of Emergency Feeding Organizations (EFOs) in that distribution, a classification that further entrenched food banks as primary outlets for government food distributions (Poppendieck 1998). Besides a hiatus between 1994 and 1996 in which a commodity glut meant no monies were allocated to TEFAP purchases, the program stabilized into a steady $\$ 140$ million appropriation every year through 2009 .

The fallout from the 2008 financial crash saw the Obama administration respond with a large TEFAP expansion through the American Recovery and Reinvestment Act (ARRA). Alongside a spike in commodity purchases, ARRA administrative funding for TEFAP more than doubled in FY 2009 and 2010 and $\$ 6$ million dollars in infrastructure grants were made available for food banks to expand their storage and distribution capacity. Six years later, as debates raged about cutting SNAP and other food entitlement programs that had ballooned following the Great Recession, the 2014 farm bill quietly increased the amount of funds appropriated to purchase TEFAP foods expanding funding for the program by 35\% through 2023 (Agricultural Act of 2014). This was the largest proportional increase to a federal nutrition program under the bill that shapes and projects future US food policy. While other entitlement programs are constantly under threat, charitable food purchases were on a healthy growth trajectory. The operations branch chief overseeing TEFAP disbursements at the USDA-FNS in fact, had a premonition that TEFAP would continue to gain importance over the coming decade. In 2017 she put it this way:

Right now, TEFAP is at its highest allocation ever at $\$ 350$ million per year and next year will be $\$ 400$ million. Could it go up to $\$ 1$ billion? I think the [Trump] administration would like it to because there is a direct relationship between TEFAP and industry. I mean it's

\footnotetext{
8 TEFAP food and funding is divided between states based on a statutory formula derived from poverty and unemployment statistics in each state. The so called "fair share" proportion is an index weighted at $60 \%$ of households living below poverty and $40 \%$ of the previous year's average unemployment rate. Statistics are drawn from the Census Bureau for the former and the Bureau of Labor Statistics for the latter. Every year the proportion of food and funding provided to states is recalculated based on updated statistics from these two federal agencies. Although poverty and unemployment are not necessarily the most telling food insecurity indicators (Gundersen 2011), the formula's codification in 1996 now makes it difficult to change, considering some states would gain at the expense of others losing out on resources if the formulas were revisited.
} 
not huge, but $\$ 350$ million is nothing to sneeze at! (2.15.17)

In February 2018, the Trump administration released a federal budget that proposed to drastically reduce SNAP spending by $\$ 213$ billion over the next 10 years, a 30\% cut. At the time, forty-three million people relied on SNAP to access food at food retail outlets across the United States and the steep reductions proposed thus had to be mitigated by some programmatic alternative. Enter America's Harvest Box which proposed "a bold new approach" to draw from SNAP savings to purchase "100-percent American grown foods provided directly to households" (Office of Management and Budget 2018, p. 15). The announcement received significant pushback from the retail and manufacturing lobby that would lose out on SNAP dollars and a public concerned about the proposed reliance on food charities and non-profits to coordinate the distribution of these boxes. As public debate over the program raged however, very little attention was focused on the supply-side logics driving the idea.

An executive order in July of that same year released $\$ 12$ billion dollars in federal aid to bail out US farmers caught up in retaliatory tariffs of an escalating trade war with China (Paleta and Dewey 2018). Agricultural producers in the crosshairs of US isolationist policies were suddenly burdened by surpluses that no longer had a market, demanding a response from the government. Over the next 2 years $\$ 2.6$ billion dollars'-worth of commodity purchases were added to existing TEFAP allocations, literally flooding regional food banks with excess product, even as national food insecurity rates were showing encouraging signs of decline. The short timeline between the America's Harvest Box announcement and the tariff related producer bailouts raise further questions about the contemporary policy links between food charities and broader political economic pressures of a profit driven food system seemingly negotiating permanent crisis.

Even as food banks were dealing with the sudden influx of trade mitigation TEFAP commodities, COVID-19 brought on even more supply chain disruptions, especially for farmers and food processors producing for the food service sector. The Families First Coronavirus Response Act passed in March appropriated \$400 million in TEFAP purchases and $\$ 100$ million in administrative reimbursement for food banks. The Coronavirus Aid Relief and Economic Security (CARES) Act passed shortly thereafter also spilt significant ink for food charity including $\$ 450$ million appropriation for TEFAP. Appropriations from both these stimulus packages were also used to establish CFAP and its attendant Farmers to Families Box Program, a policy intervention extremely familiar to those who had tracked the earlier America's Harvest Box proposal.
Drawing on authority in the CARES act to borrow up to $\$ 14$ billion through the CCC and $\$ 9.5$ billion to purchase surplus from specialty crop producers, USDA-AMS rapidly devised a program to connect food waste to food charities through a bidding process that enrolled new for profit supply chains (mostly from the food service sector) into charitable food networks. Still in its infancy, the program has had a very rocky start, adding additional burdens on food banks, and raising questions over the large sums of money awarded to private contractors promising to deliver surplus into a network that many heretofore had no real knowledge about. (Bottemiller Evich and McCrimmon 2020).

As detailed above, the history of U.S. nutrition assistance policy is intimately tied to resolving crises of overproduction along agricultural circuits (Graddy-Lovelace and Diamond 2017). The significant evolution in the case of TEFAP, and now CFAP, is the overt enrollment of private charities to distribute the surplus. Public food procurement programs serve to anchor food charity in place, legitimizing food banks and their network of LFCs as appendages of state policy. As the state relies more and more heavily on charity to stabilize agricultural markets, private businesses find increased opportunities to negotiate lucrative contracts with the federal government without engaging in any of the fundraising, logistical and care work that food charities are involved in to feed the proverbial line.

Public procurement programs are also overwhelmingly associated with rules, burdensome bureaucracy and red tape. As one food bank director in West Virginia complained:

Ultimately our work is to get food out to people, but sometimes the bureaucracy of the business overwhelms it. There is so much paperwork! Are we feeding people or getting information from them? TEFAP is especially bad, we are losing TEFAP agencies because it's just too much work for them. Rules have gone from a few pages to a book. I mean, how much can you burden volunteers with this? I've volunteered for a lot of things before, but one thing is for sure, I've never volunteered to do paperwork!" (7.8.16)

The public procurement rulebook serves three different purposes for the state. First, it ensures that surplus purchased by the federal government remains locked in non-profit distribution channels that will not disrupt agricultural markets. Local charities are forbidden from exchanging or selling the commodities they receive; they must give them away. Second, the rules ensure non-discrimination and equitable distribution of these gifts regardless of race, gender, age, or disability. The social justice statutes work to expand access to emergency food to the widest extent possible and codify emergency food as an entitlement for all who qualify under state guidelines. Third, the foods must meet certain nutritional standards and are regularly monitored for 
Table 1 Feeding America Member Contract Adapted from the 2014 FA member contract

\begin{tabular}{llll}
\hline General terms & Administrative requirements & Management and governance & Non compliance policies \\
\hline Service Agreements & Community Support & Staffing & Probation \\
Service Area & Compliance Auditing & Board of Directors & Suspension \\
Member Fees & Financial Records & Distribution Partners & Termination \\
Communication & Financial Stability & Organizational Structure & Expedited Termination \\
Conflict Resolution & Insurance & Use of Feeding America Name & Service Area Reassignment \\
Logo and Trademark Use & Legal Responsibilities & Warehouse and Storage & \\
\hline Operations & & & \\
\hline Local agencies & Product donations & Food safety & \\
\hline Elligibility (501c3) & Allocation & Audits & \\
Documentation & Distribution & Facilities & \\
Record Keeping & Reporting & Handling & \\
Monitoring & Training & \\
& Monitoring & & \\
\hline
\end{tabular}

The full 72-page document establishes the obligations of each contracting party across the FA network and the rules governing food donations

quality through the AMS contracting process. Public food procurement across charitable food networks then is not only a regulatory apparatus, not only a vehicle for ensure new opportunities for accumulation in the food system, but also a site of struggle over whom emergency food networks should ultimately serve. In many ways the rules informing access to TEFAP provide a basis for thinking about a right to food framework that other charitable food institutions such as FA do not mandate.

\section{Private procurement}

The links between private food corporations and food charities is more and more visible as cause marketing campaigns claim to provide meals to people in need while reducing the negative environmental impacts of food waste. Walmart's Fight Hunger Spark Change campaign was launched in 2014 to provide 4 billion meals to people struggling with hunger by 2020. In 2017, the Kroger corporation followed suit with its Zero Hunger I Zero Waste plan to donate 3 billion meals by 2025 , the same year it aims to meet a zero-food waste goal across the company. Such commitments secure cultural legitimacy in the marketplace while improving brand loyalty and increasing shareholder returns (Warshawsky 2016). Yet, Kroger and Walmart do not provide meals to people. Rather they donate their food waste to the large non-profit Feeding America (FA). This nuance is important because their corporate benevolence ultimately relies on partnerships with food charities working to recover and redistribute this waste on their behalf.

Competition over resources in the non-profit sector tends to bifurcate civil society organizations along lines of volunteerism and expertise creating social distance between administrative centers that regulate and oversee the distribution of resources, and the community-based organizations that these were initially set up to serve (Milligan 2007). On one end of the spectrum are small volunteer based "grassroots" organizations that address local needs through local partnerships, such as LFCs. On the other are non-profits tightly linked to government or industry concerns who operate according to the prevailing logics of corporate culture in a market society (Dahrendorf 2003). With its formalized corporate donor base and over $\$ 2$ billion balance sheet, FA is a non-profit that fits within this highly professionalized and corporatized tier of the shadow state (Wolch 1990).

Food corporations donated 3.3 billion pounds of food waste to Feeding America (FA) in 2017, a number that doubled in less than a decade. FA brokers the relationship between corporate donors, its 200-member food banks and their 60,000 LFC affiliates through a 72-page contract that defines the terms of the relationship among these various actors across nearly every aspect of food banking operations (Table 1). Food charities sourcing food waste within the FA ecosystem are contractually obligated to comply with policies ranging from financial record keeping, food safety, board governance and the trademarked use of the FA brand. The contract delimits each food bank's service territory, ordering and disciplining FA members amongst themselves and regulating the flow of donated food waste across space. Like the USDA, FA also explicitly forbids food banks or their local affiliates from reselling donated food products.

FA provides legitimacy and brand recognition to food banks operating in an increasingly competitive philanthropic environment. One West Virginia food bank director 
summarized her organization's relationship to the "mother ship" as follows :

Feeding America holds their food banks to the highest standards, by partnering with them we show potential partners that we are not just a fly by night organization. [...] Of course Feeding America is concerned about putting their name on our operation. When they ask a major donor to give food or money they know it is safe because they are monitoring us." (5.14.14)

Food charities that operate without an FA affiliation however are increasingly struggling to maintain relationships with their food donors. One non-affiliated food bank director for example recounted:

One day one of my long-time donors just stopped giving food to me overnight. They said I wasn't a Feeding America affiliate and their corporate made them stop giving to us. I don't know how FA has that kind of power but they're snatching my people away from me." (9.13.17)

This centralization of power did not happen overnight. The early years of food banking were about building individual relationships with businesses willing to donate excess food to hunger relief causes. An early obstacle to private firms donating food to charity however was the fear of legal liability. California first passed a Good Samaritan law absolving food donors from this risk in 1977, and by the late 1980s all 50 states had some form of Good Samaritan laws on the books. As FA (formerly Second Harvest) operations expanded across the country, the lack of legal uniformity prevented the organization from acting in concert to broker tax deductions for national level donors. After lobbying by FA and its corporate partners, Clinton signed The Bill Emerson Good Samaritan Act into law in 1996 absolving $\mathrm{C}$ corporations from liability, save in cases of gross negligence. Donors no longer had to navigate 50 different state laws and could now take full advantage of federal tax incentives through a clearly defined valuation for donated food products. The Good Samaritan Act increased food waste donations to charity from the private sector significantly, doubling from 900 million pounds to 1.8 billion pounds in the period between 1996 and 2002 (O'Brien et al. 2004).

Private firms continued to leverage their relationship with FA to increase tax relief opportunities (Van Zuiden 2012). Years of FA lobbying efforts to amend the tax code in favor of corporate food donors were rewarded through the Protecting Americans from Tax Hikes Act (PATH Act), which took effect on January 1st, 2016. The PATH Act increased the cap of allowable charitable contributions for food corporations from 10 to $15 \%$ of net income and codified an important court ruling for food donors by expanding the Lucky Stores, Inc. v. Commissioner of Internal Revenue (1995) case nationally ${ }^{9}$ (U.S. Internal Revenue Service, C.F.R. 26-170). The law now allows retailers to assess a uniform FMV on the original selling price of their donation no matter the quality of the product being donated. In other words, while food items nearing expiration lose value in the marketplace due to spoilage or expiration, they no longer do if they are converted to a gift channeled through a charitable food supply chain. A food bank director summed up her frustration with the material values ascribed to food waste as hunger relief as follows:

The things that I have to give to people are often things that you and I won't buy. We walk right past it. Sometimes we'll receive product and I just say, I'm not distributing that, I don't think you want me to identify that you donated that product. They want the credit for the donated food, and then we go into a county, we have our compliance standards [from Feeding America] so we want the credit for putting that food out. (5.12.17)

Though FA is a $501 \mathrm{c} 3$ non-profit organization, it is largely beholden to the profit motives of private companies, those sitting as representatives on its board of directors and those donating food and funds to its mission. ${ }^{10}$ Member food banks must conform to network wide FA practices, including meeting regular distribution targets, or face the scepter of declining private food procurement options and a struggle for fiscal survival in a philanthropic environment that increasingly demands the legitimacy of professionalized institutions. FA's ability to govern such a vast private food waste revaluation network rests on an accounting technique known as "variance power". FA owns donated food waste as an asset, transferring it to third party beneficiaries through the legal contract reviewed above. Food banks must report the number of pounds received from each corporate donor to FA, who then consolidates these numbers to process tax deductible receipts on their behalf. A food banking product sourcing manager in West Virginia explained the

\footnotetext{
9 The Internal Revenue Service contended that Lucky Stores donations of 4-day old bread did not warrant a full retail value tax deduction. They argued that the industry practice of most bakers was to discount aged bread and thus the fair market value should be half the retail price. Lucky stores would have received no tax benefit at this valuation rate and thus brought the issue to tax court. The judge ruled in favor of Lucky stores determining the value of surplus bread inventory donated to a qualified charity was the same as the full retail price of that bread.

${ }^{10}$ Claire Babineaux-Fontenot, FA's current CEO, is a former executive VP at Walmart, and Matt Knott whom she replaced in 2018 was formerly an executive for PepsiCo. The board also includes representatives from Kroger, ConAgra, and General Mills. These are some of the most powerful corporate food firms in the world. FA's power to shape the charitable food sector elevates the organization as a key arbiter legitimizing the anti-hunger activities of food corporations vis-à-vis the state and the public.
} 
daily accounting procedure he must follow: "Everything we receive is receipted to corporate Walmart and Kroger by store date and product category. We have to receipt to Feeding America, they give credit back to the stores. If we receipt for $80 \mathrm{lb}$ and they gave $100 \mathrm{lb}$, they get mad at us" (8.8.14).

Tax deductible receipts must meet the criteria outlined in the Internal Revenue Service (IRS) code 170(e)3, namely that donations be provided "for the care of the ill, needy, or infants". Headquartered in Chicago, FA is far removed from most of the people ultimately consuming the food waste it takes ownership over, it is also far removed from the organizations actually handling this food on a daily basis. FA compliance and capability officers perform regular food bank audits to ensure contracts are upheld and that donated food waste circulates exclusively through their certified non-profit pipeline toward the penultimate satiation of a hungry body. To this end, FA requires that food banks and LFCs follow the letter and spirit of the Internal Revenue Service (IRS) code 170(e)3 regardless of whether the donor ultimately reports these food gifts as tax deductible donations at the end of the year or not. This latter point is key to understanding how corporate food waste becomes enclosed within a charitable food supply chain that benefits the food industry.

Only a small percentage of the billions of pounds of food waste circulating in this gift economy each year are reported to the IRS as a tax deduction. This was confirmed by the FA director of retail partnerships during a conversation about the relationship between corporate food donations and tax incentives:

Large national FA donors cap out on their charitable giving, often without even sometimes taking into consideration the food that they donate, so the food is just kind of extra. It may not impact their bottom line in terms of taking a deduction, but where it impacts their bottom line is they are not paying for dumping or disposal fees and then they have a wonderful story to be able to tell in every community that they are located on what they are doing to decrease waste and lessen their carbon footprint and at the same time feed people in that community where the store is operating. (FA Interview, 4.23.15)

By treating all donated foods as tax-deductible gifts however, FA draws on the tax code to enclose waste within charitable food supply chains thereby ensuring that food waste will not be repurposed toward alternative and diverse economic practices that might disrupt profitability along primary food commodity circuits (e.g. discount food retailers, value added processing operations, etc.) The main effect of these regulations is that any food bank or LFC receiving FA product must raise money to pay staff and recruit volunteers to give this food away, yet the labor and distribution costs cannot be subsidized through the sale of the food commodity they handle as would be the case in most functioning food markets.

Food charities in breach of contract are placed on probation for failing to meet FA standards. Suspension or termination leads to a loss of access to donations secured through FA's corporate partnerships. Because food banks now depend so heavily on corporate food sources, exclusive grant opportunities and the brand recognition that FA provides to sustain its own philanthropic outreach, this carrot and stick approach has been highly successful, bringing uniformity to what is otherwise an amorphous group of organizations providing hunger relief across the country. Yet grassroots LFCs wrapped up in this governance structure have very little power to shape these rules, and food recipients struggling to secure food entitlements have even less agency in determining how these food flows might be reimagined to meaningfully address their community's needs. The tight governance structure regulating private food procurement across charitable food networks in the United States raises pressing questions regarding whose interests are ultimately driving the expansion of food waste as hunger relief.

\section{Conclusion}

Most will agree that a society in which 46 million people depend on charity to survive is unjust, yet they tend to situate these injustices within a demand side framework. I have argued here that supply-side dynamics are key to understanding why the demand for emergency food is maintained through food charity. The focus on food access failures at the household level, while clearly important, often obscures the perverse dynamics that enclose massive food surpluses within distribution channels that decriminalize excess and reinforce a politics of scarcity by regulating abundance. The data and ideas around food waste enclosure presented here might further a research agenda that begins to pose deeper questions about the links between the production of food waste, the production of hunger, and the food and nutrition policies that reinforce both.

The data presented here reveals how food waste transfers into the charitable food economy are tightly controlled by the state and large agro-industrial food concerns to ensure that they do not disrupt the scarcity logics and profit imperatives currently driving the biopolitics of food provisioning writ large (Nally 2011). After 40 years of increasingly sophisticated governance mechanisms from both the public and private food and agricultural sectors, food banks are now woven into the fabric of an industrial food system that accumulates wealth by revaluing waste as hunger relief. As the COVID-19 crisis adds political pressure to address food waste crises through hunger relief, it is critical to attend to the politics of production structuring 
charitable food circuits, not merely the politics generating the demand for emergency food. Indeed, food system scholars and anti-hunger advocates must come to realize how tightly the two are linked.

At the root of this phenomenon is the question of ownership and access to food waste, whether it should be understood as a commons or continue to be regulated within the private property relations that previously gave it value (Vivero-Pol 2017). This question is especially important as new food waste governance regimes begin to emerge. In 2015 for example, a cross-sectoral partnership between large food businesses, environmental groups, foundations and public agencies organized to tackle the food waste problem under the banner "Rethink Food Waste through Economics and Data" (ReFED). FA is a member of the advisory council along with the USDA and corporate food executives representing the likes of General Mills, Campbell's Soup, Publix, Sodexo, Target and Walmart. ReFED advocates for legal and institutional changes that promise to create new jobs while fostering entrepreneurial innovation and emergent profit centers across the food industry, all while reducing hunger. Their roadmap to cutting U.S. food waste by $20 \%$ in a decade proposes market-based solutions that present "a unique opportunity to protect the American economy, conserve natural resources, create jobs, reduce the tax burden, and feed the nearly 50 million Americans who experience food insecurity." (ReFED 2016, p. 83).

In April 2018, the first bi-partisan food waste caucus met in the U.S. House of Representatives to highlight the social contradictions of food waste in the context of food insecurity (Pingree 2019). The 2018 Farm Bill recently funded several novel food waste reduction pilot programs and market subsidies that connect food waste and want. It also created a new Food Loss and Waste Reduction Liaison at the USDA to coordinate efforts across federal programs. States across the country are writing and passing their own laws to reduce food waste or connect agricultural surplus to the hungry. The legal geography of food waste enclosure is thus ripe for further exploration.

Those writing and amending the laws and the contracts that enforce food waste regimes need to pay close attention to whose ability to avoid risk they are prioritizing when it comes to hunger relief. Compassion for hunger related causes is a powerful force structuring the economies of care involved in revaluing industrial food waste. If nutrition policies ensured a right to food for all however, and hunger ended today, would it still be as morally and politically palatable to lay the burdens of resolving the food waste problem on the shoulders of civil society organizations? To phrase that question differently, and perhaps more directly, to what extent does the current food system rely on hunger to solve its food waste problem? Approaching our social contract with those questions in mind would surely advance a more just approach to the food waste problems we collectively face.

Acknowledgements I would like to thank Mountaineer and Facing Hunger food banks, along with the many other charitable food organizations in West Virginia and beyond that volunteered their time and assistance in the research process. Bradley Wilson, Adam Pine, Alida Cantor and Joshua Barkan offered helpful comments and direction on early versions of the manuscript. The legal geographies specialty group of the American Association of Geographers provided a forum for public feedback. Reactions from four anonymous reviewers also helped shape the paper into this final version. Any errors and misrepresentations are my responsibility.

\section{References}

Agricultural Act of 2014, 113 P.L. 79, 128 Stat. 649, 2014 Enacted H.R. 2642, 113 Enacted H.R. 2642 (February 7, 2014).

Araghi, F. 2003. Food regimes and the production of value: Some methodological issues. The Journal of Peasant Studies 30 (2): 41-70.

Arcuri, S. 2019. Food poverty, food waste and the consensus frame on charitable food redistribution in Italy. Agriculture and Human Values 36 (2): 263-275.

Billo, E., and A. Mountz. 2016. For institutional ethnography: Geographical approaches to institutions and the everyday. Progress in Human Geography 40 (2): 199-220.

Blake, M. 2019. The multiple ontologies of surplus food. Europe Now 27: $1-9$.

Bloom, J. 2010. American Wasteland: How America Throws Away Nearly Half of Its Food (and What We Can Do About It). Cambridge, MA: De Capo Press.

Bottemiller E. and McCrimmon, R. 2020. Multi-million food bank delivery contracts go to firms with little experience. Politico. https ://www.politico.com/news/2020/05/13/usda-food-bank-contracts256452. Accessed 14 May 2020.

Broad Leib, E., et al. 2017. Opportunities to reduce food waste in the 2018 Farm Bill. Cambridge: Food Law and Policy Clinic. Harvard Law School.

Burch, D., and G. Lawrence. 2009. Towards a third food regime: Behind the transformation. Agriculture and Human Values 26 (4): 267-279.

Chappell, M.J. 2018. Beginning to End Hunger: Food and the Environment in Belo Horizonte, Brazil, and Beyond. Berkeley, CA: Univ of California Press.

Coleman-Jensen, A. et. al. 2016. Household Food Security in the United States in 2015. ERR-215, U.S. Department of Agriculture, Economic Research Service, September 2016.

Commodity Credit Corporation Charter Act, amendment., 81 P.L. 85, 63 Stat. 154, 81 Cong. Ch. 175 (June 7, 1949).

Dahrendorf, R. 2003. Forward in J. Kendall. The Voluntary Sector, xiii-xvi. London: Routledge.

De Castro, J. 1977. The Geopolitics of Hunger. New York, NY: Monthly Review Press.

Dickenson, M. 2020. Feeding the Crisis: Care and Abandonment in America's Food Safety Net. Berkeley, CA: University of California Press.

Duffy, R. 2014. What does collaborative event ethnography tell us about global environmental governance? Global Environmental Politics 14 (3): 125-131.

Feeding America. 2017. Annual Report. https://www.feedingamerica. $\mathrm{org} / \mathrm{sites} / \mathrm{default} /$ files/aboutus/-financials/2017-feeding-americaannual-report.pdf. Accessed 15 August 2018. 
Fisher, A. 2017. Big Hunger: The Unholy Alliance Between Corporate America and Anti-hunger Groups. Cambridge, MA: MIT Press.

Forney, J. et al. 2018. Agri-Environmental Governance as Assemblage: Multiplicity, Power and Transformation. London: Routledge.

Friedmann, H. 2005. From colonialism to green capitalism: Social movements and the emergence of food regimes. In New Directions in the Sociology of Global Development. Research in Rural Sociology and Development, vol. 11. ed. F.H. Buttel and P. McMichael, 229-267. Oxford: Elsevier.

Galli, et al. 2019. Food waste reduction and food poverty alleviation: A system dynamics conceptual model. Agriculture and Human Values 36 (2): 289-300.

Galt, R. 2013. Placing food systems in first world political ecology: A review and research agenda. Geography Compass 7 (9): 637-658.

Gille, Z. 2012. From risk to waste: Global food waste regimes. The Sociological Review 60: 27-46.

Graddy-Lovelace, G., and A. Diamond. 2017. From supply management to agricultural subsidies and back again? The U.S. Farm Bill \& agrarian (in)viability. Journal of Rural Studies 50: 70-83.

Gundersen, C., et al. 2011. The Economics of Food Insecurity in the United States. Applied Economic Perspectives and Policy 33 (3): 281-303.

Henderson, G. 2004. 'Free' food, the local production of worth, and the circuit of decommodification. Environment and Planning $D$ 22 (4): 485-512.

Heynen, N., and P. Robbins. 2005. The neoliberalization of nature: Governance, privatization, enclosure and valuation. Capitalism Nature Socialism 16 (1): 5-8.

Lambie-Mumford, H. 2019. The growth of food banks in Britain and what they mean for social policy. Critical Social Policy 39 (1): 3-22.

Landers, P.S. 2007. The food stamp program: History, nutrition education, and impact. Journal of the American Dietetic Association 107 (11): 1945-1951.

Lindenbaum, J. 2016. Countermovement, neoliberal platoon, or re-gifting depot? Understanding decommodification in US food banks. Antipode 48 (2): 375-392.

Lipsky, M., and M. Thibodeau. 1988. Feeding the Hungry with Surplus Commodities. Political Science Quarterly 103 (2): 233-244.

Lohnes, J., and B. Wilson. 2018. Bailing out the food bank? Hunger relief, food waste and crisis in Central Appalachia. Environment and Planning A: Economy and Space 50 (2): 350-369.

Lorenz, S. 2012. Socio-ecological consequences of charitable food assistance in the affluent society: The German Tafel. International Journal of Sociology and Social Policy 32 (7/8): 386-400.

Lucky Stores v. Commissioner, 105 T.C. 420, 1995 U.S. Tax Ct. LEXIS 65, 105 T.C. No. 28 (United States Tax Court December 19, 1995, Filed).

McIntyre, L. et al. 2016. "In"-sights about food banks from a critical interpretive synthesis of the academic literature. Agriculture and Human Values 33 (4): 843-859.

McMichael, P. 2009. A food regime genealogy. Journal of Peasant Studies 36 (1): 139-169.

Midgley, J. 2014. The logics of surplus food redistribution. Journal of Environmental Planning and Management 57 (12): 1872-1892.

Milligan, C. 2007. Geographies of volunteerism: Mapping the terrain. Geography Compass 1 (2): 183-199.

Moore, S. 2012. Garbage matters: Concepts in new geographies of waste". Progress in Human Geography 36 (6): 780-799.

Mourad, M. 2016. Recycling, recovering and preventing "food waste": Competing solutions for food systems sustainability in the United States and France. Journal of Cleaner Production 126: 461-477.

Nally, D. 2011. The biopolitics of food provisioning. Transactions of the Institute of British Geographers. 36 (1): 37-53.
O'Brien, D, et al. 2004. The Charitable Food Assistance System: The Sector's Role in Ending Hunger in America. Savannah, GA: America's Second Harvest.

Office of Management and Budget. 2018. Budget of the U.S. Government. Fiscal Year 2019. https://www.whitehouse.gov/wp-conte nt/uploads/2018/02/budget-fy2019.pdf. Accessed 1 Sept 2020.

Paleta, D., and C. Dewey. 2018. White House readies plan for $\$ 12$ billion in emergency aid to farmers caught in Trump's escalating trade war. Washington Post: July 25th, 2018.

Peck, J., and A. Tickell. 2002. Neoliberalizing space. Antipode 34 (3): 380-404.

Pingree, C. 2019. Pingree, Newhouse, Co-Chairs of Bipartisan Congressional Food Recovery Caucus, Applaud Presidential Message Promoting Food Waste Reduction in April. Retrieved September 01, 2020, from https://pingree.house.gov/news/documentsingle. aspx? DocumentID=2031.

Poppendieck, J. 1998. Sweet Charity? Emergency Food and the End of Entitlement. New York: Penguin Books.

Poppendieck, J. 2014. Breadlines Knee Deep in Wheat. Food Assistance in the Great Depresssion. Berkeley: UC Press.

ReFED. 2016. A roadmap to reduce U.S. foodwaste by 20 percent.https ://www.refed.com/downloads/-ReFED_Report_2016.pdf.

ReFED. 2019. ReFED Annual Report. https://www.refed.com. Accessed 21 April 2020.

Riches, G. 2018. Food Bank Nations: Poverty, Corporate Charity and the Right to Food. New York, NY: Routledge.

Riches, G., and T. Silvasti. 2014. First World Hunger Revisited: Food Charity or the Right to Food?, 2nd ed. London: Palgrave Macmillian.

Roy, A. 2020. The Pandemic is a portal. Financial Times, April 3rd, 2020.

Salonen, A. 2018. Religion, poverty and abundance. Palgrave Communications 4 (1): 1-5.

Sen, A. 1981. Poverty and Famines: An Essay on Entitlement and Deprivation. Oxford, U.K.: Oxford University Press.

Spring, C., et al. 2020. Food waste: an introduction to contemporary food waste studies. In Routledge Handbook of Food Waste, ed. Reynolds, C. et al., 1-19. New York, NY: Routledge.

Stuart, T. 2009. Waste: Uncovering the Global Food Scandal. New York: W. W. Norton.

U.S. Department of Agriculture. 2020. Additional information on FY 2020 funding sources for TEFAP. https://www.fns.usda.gov/tefap/ additional-information-fy-2020-funding-sources. Accessed $1 \mathrm{Sept}$ 2020.

U.S. Internal Revenue Service. Charitable, etc. contributions and gifts. Code of Federal Regulations 26-170.

Van Zuiden, S. 2012. The good food fight for good Samaritans: The history of alleviating liability and equalizing tax incentives for food donors. Drake Journal of Agricultural Law 17 (1): 237-262.

Vasudevan, A., et al. 2008. Spaces of enclosure. Geoforum 39 (5): 1641-1646.

Vernon, J. 2007. Hunger: A Modern History. Cambridge, MA: Harvard University Press.

Vivero-Pol, J. 2017. Food as commons or commodity? Exploring the links between normative valuations and agency in food transitions. Sustainability 9: 442.

Warshawsky, D. 2010. New power relations served here: The growth of food banking in Chicago. Geoforum 41: 763-775.

Warshawsky, D. 2016. Food waste, sustainability, and the corporate sector: Case study of a US company. The Geographic Journal 182 (4): 384-394.

Watts, M., and H. Bohle. 1993. Hunger, famine and the space of vulnerability. GeoJournal 30 (2): 117-125.

Weinfield, N. et al. 2014. Hunger in America report. Feeding America.

Wolch, J. 1990. The Shadow State: Government and Voluntary Sector in Transition. New York: Foundation Center. 
Publisher's Note Springer Nature remains neutral with regard to jurisdictional claims in published maps and institutional affiliations.

Joshua D. Lohnes is the Food Policy Research Director in the Center for Resilient Communities at West Virginia University. As a social geographer, he studies the moral, political and economic dimensions of food access across space and time with a focus on humanitarian food networks. As a scholar-activist he develops action research projects through data sharing tools, planning and educational resources that support the development of anti-hunger and food sovereignty coalitions in West Virginia and beyond. 